\title{
RESPONSE OF THE WOLF (CANIS LUPUS LINNAEUS, 1758) POPULATION TO VARIOUS MANAGEMENT REGIMES AT THE EDGE OF ITS DISTRIBUTION RANGE IN WESTERN POLAND, 1951-2012
}

\author{
NOWAK, S. ${ }^{1^{*}}-$ MYSŁAJEK, R. W. ${ }^{2}$ \\ 'Association for Nature “Wolf”, Twardorzeczka 229, 34-324 Lipowa, Poland \\ ${ }^{2}$ University of Warsaw, Faculty of Biology, Institute of Genetics and Biotechnology, \\ Pawińskiego 5a, 02-106 Warszawa, Poland \\ *Corresponding author \\ e-mail: sabina.nowak@polishwolf.org.pl \\ (Received $6^{\text {th }}$ Aug 2016; accepted $28^{\text {th }}$ Feb 2017)
}

\begin{abstract}
We investigated the number, distribution and human-caused mortality of wolves in western Poland during different management regimes. During intensive eradication (1951-1974) at least 49 wolves were exterminated (on average 2.6 wolves per year), and the species was reported in up to 4 forests per year (mean 1.7), but most of the family groups bred only once before being killed. Under hunting management (1975-1997) wolves were recorded in 1-4 forests per year (mean 3.1). Most of them did not breed or bred only once before they were harvested in the first year after detection. During this time period at least 70 individuals were harvested (on average 3.0 wolves per year). After the wolf became a protected species in 1998, the number of wolf groups increased to 30 in winter 2012/2013, while the number of forests inhabited by wolves increased to 14 . Our study provides further confirmation that recreational hunting conducted in populations of wolves living far from a source of immigrants, in areas heavily altered by humans, where access by hunters to the most distant refuges is enabled by a dense network of forest roads, has a detrimental impact on wolf survival comparable to the effects of systematic eradication. We recommend that management plans for such subpopulations should be preceded by careful analysis of population viability and connectivity with source populations.
\end{abstract}

Keywords: carnivore conservation, persecution, hunting, species range, population recovery

\section{Introduction}

Management strategies for the wolf (Canis lupus Linnaeus, 1758) vary considerably - from total persecution, to strict protection - across its vast range in the Northern Hemisphere (Boitani, 2003). After decades of intentional killing, which in many cases led to the complete eradication of the species, conservation regimes were tightened. The implementation of new legislations (e.g. Bern Convention, EU Habitats Directive, US Endangered Species Act), which limited wolf hunting, resulted in the recovery of the species in large parts of Europe (Chapron et al., 2014) and Northern America (Ripple et al., 2014).

Annual wolf population growth rates are usually high in newly recolonized areas, or regions where heavy harvest is stopped (Wydeven et al., 1995; Pletscher et al., 1997; Wabakken et al., 2001). Thus, wolves may rebound quickly if there is a source of immigrants nearby (Hayes and Harestad, 2000), even in areas with relatively high human density (Nowak et al., 2008). Although the presence of large carnivores may be beneficial for preservation of biodiversity and maintenance of ecosystem functions and services (Duffield et al., 2008; Ripple et al., 2014; Kuijper et al., 2015), there is also the apprehension that the species will expand into human-altered environments (e.g. 
agricultural or urbanized), which may increase human-predator conflicts (Mech, 1995). Therefore, lethal control has been suggested as a remedy to limit wolf damage to livestock and pets (Boitani, 2003).

Wolf populations may be numerically stable even if human-caused mortality exceeds $30 \%$ annually (Fuller et al., 2003). Such 'stability' is usually maintained by the immigration of individuals from surrounding populations or by the high reproductive rate of wolf parental pairs, which form the core of family groups (Fuller, 1989; Ballard et al., 1997; Larivière et al., 2000). Nonetheless, harvesting has a profoundly negative effect on the socio-spatial organization of wolf populations (Rich et al., 2012; Bryan et al., 2014), and the killing of breeding individuals often leads to pack dissolution (Brainerd et al., 2008; Borg et al., 2015). These consequences are particularly important in regions far from sources of immigrants, where the absence of suitable mates in a population may lead to extinction due to Allee effects (Stenglein and van Deelen, 2016).

In Poland during the twentieth century wolves were never totally extirpated even though human pressure on them was very high. For example, in eastern Poland (hereinafter EPL) and the Carpathian Mountains, in winter hunting season 1951/52 wolf number was estimated on 820 wolves, 156 wolves were shot, and 46 pups were removed from natal dens in summer 1952 (Kowalski, 1953). In spite of these efforts the wolf population was still estimated by hunters to be over 1,000 individuals in early 1953, and the species' range expanded in EPL, several wolves were also observed in the central and western parts of the country (Kowalski, 1953). Therefore, the Polish government, pressed by hunters, introduced a nation-wide wolf eradication programme in the mid-1950s (Okarma, 1993).

Deliberate persecution by removal of litters, poisoning, intense hunting with guns and fladry and high bounties amounting an average monthly salary resulted in 3,316 wolves killed (on average 184 animals per year, with the highest number 425 kills in 1956 and 1958 and the lowest number 59 kills in 1971) in the whole of Poland between 1954-1972. This caused a significant decline in the population, to about 60 wolves in 1972 (Sumiński, 1975). The species' range shrank so much that even single wolves were no longer observed in western and central Poland, while some survivors were recorded in several forests of the easternmost part of the country, near the state borders with Russia (Kaliningrad District), Lithuania, Belarus and Ukraine, and in the eastern part of the Carpathian Mountains (Wolsan et al., 1992). The eradication programme was finally terminated in the mid-1970s.

In 1975 the wolf was re-included on the game list, and at the end of 1981 a four month closed season (from April 1 to July 31) was introduced across the country. Over the next 23 years of hunting management ca. 2,200 wolves were killed (on average 94 individuals per year) by hunters, mainly in EPL and the Carpathians (compiled data of the Polish Central Statistical Office and the Research Station of the Polish Hunting Association). During the initial eleven years of harvesting the species' range increased in EPL and the Carpathian Mts., and the number of wolves grew to a maximum of 960 individuals in 1986, but subsequently decreased to about 850 wolves in 1994. However, wolves were still very rare in western Poland (hereinafter WPL) (Sumiński, 1973; Okarma, 1989, 1993).

In 1998, after a long-term conservation campaign led by non-governmental organisations, wolves became strictly protected across the whole country (Mysłajek and Nowak, 2015), and in the mid-2000s they begun to re-settle the vast lowland forests of WPL (Nowak et al., 2011; Nowak and Mysłajek, 2016). The re-colonisation started 
from jump dispersal, which allowed wolves to establish packs far $(376 \pm 106.5 \mathrm{~km})$ from the source population in EPL (Czarnomska et al., 2013; Nowak and Mysłajek, 2016).

In this study we compared the number and distribution of wolves in WPL during intensive persecution (1951-1974) and hunting management (1975-1997), with the wolf population's status after introduction of strict protection in 1998. We hypothesized that in areas distant to a source of immigrants and heavily altered by humans, intensive hunting management has a detrimental impact on wolf numbers comparable to the effects of systematic eradication.

\section{Material and Methods}

\section{Study area}

Data on wolf presence after the Second World War were collected for the whole lowland part of WPL, from $18^{\circ} 48^{\prime} \mathrm{E}$ in the east to the Polish-German border in the west $\left(14^{\circ} 07^{\prime} \mathrm{E}\right)$, and from $50^{\circ} 00^{\prime} \mathrm{N}$ in the south to $54^{\circ} 17^{\prime} \mathrm{N}$ in the north (Fig. 1). The total study area covered $136,000 \mathrm{~km}^{2}$.

The region is located in the temperate climate zone, but with an oceanic character, where the mean annual temperature is $7.9-9.3^{\circ} \mathrm{C}\left(-1.1\right.$ to $0.6^{\circ} \mathrm{C}$ in January, 18.1 to $19.5^{\circ} \mathrm{C}$ in July). Mean precipitation ranges from 504 to $766 \mathrm{~mm}$ (Central Statistical Office, 2012). The length of the vegetation season is 220-240 days, while snow cover persists from 40 to 60 days.

The terrain is mostly flat (from 0 to $200 \mathrm{~m}$ a.s.l.),with several ranges of frontal and moraine hills. About $57 \%$ of the area is farmland with a predominance of arable land. After the Second World War, human density in WPL increased by 75\%, from 64 in 1950 to 108 inhabitants/km² in 2012 (Gawryszewski, 2005; Central Statistical Office, 2012, 2013). The density of public (hard-surface) roads in Poland increased from 36 $\mathrm{km} / 100 \mathrm{~km}^{2}$ in 1950 to $90 \mathrm{~km} / 100 \mathrm{~km}^{2}$ in 2012, and the increase was comparable across the whole country (Central Statistical Office, 2013, 2015). The network of modern motorways (fenced along both sides) only started to develop from 1995, from $246 \mathrm{~km}$, to $2,417 \mathrm{~km}$ in 2012 . The motorway network stretches mostly across the western and central parts of Poland (Central Statistical Office, 2013, 2015).

Forest cover increased in Poland from 21\% in 1946 to 29\% in 2012, although it has always been higher in WPL (32\% in 2012) (Zajączkowski et al., 2015). Most forests in WPL are coniferous stands (70\% of the total area) dominated by Scots pine (Pinus sylvestris, 60\% of the forest area), Norway spruce (Picea abies, 6\%), and fir (Abies alba, 3\%), with very limited undergrowth. Deciduous and mixed forests with oak (Quercus robur and Q. petraea), birch (Betula sp.), alder (Alnus glutinosa), beech (Fagus sylvatica), hornbeam (Carpinus betulus), and poplars (Populus sp.) make up about $30 \%$ of WPL's forests. The habitat suitability model for Polish wolves (Jędrzejewski et al. 2008) suggested that $63 \%$ of suitable habitat (about $39,000 \mathrm{~km}^{2}$ ) is in WPL, while only $37 \%\left(22,600 \mathrm{~km}^{2}\right)$ is in the lowlands of EPL and Carpathian Mts.

In WPL, approximately $94 \%$ of forests are public (93\% state owned), while $6 \%$ are private. Most woodlands are commercial stands with only $1.5 \%$ protected as national parks or reserves (Central Statistical Office, 2016). Since the Second World War, state owned forests in Poland have been managed by the National Forest Holding "State Forests", supervised by the Polish government. 


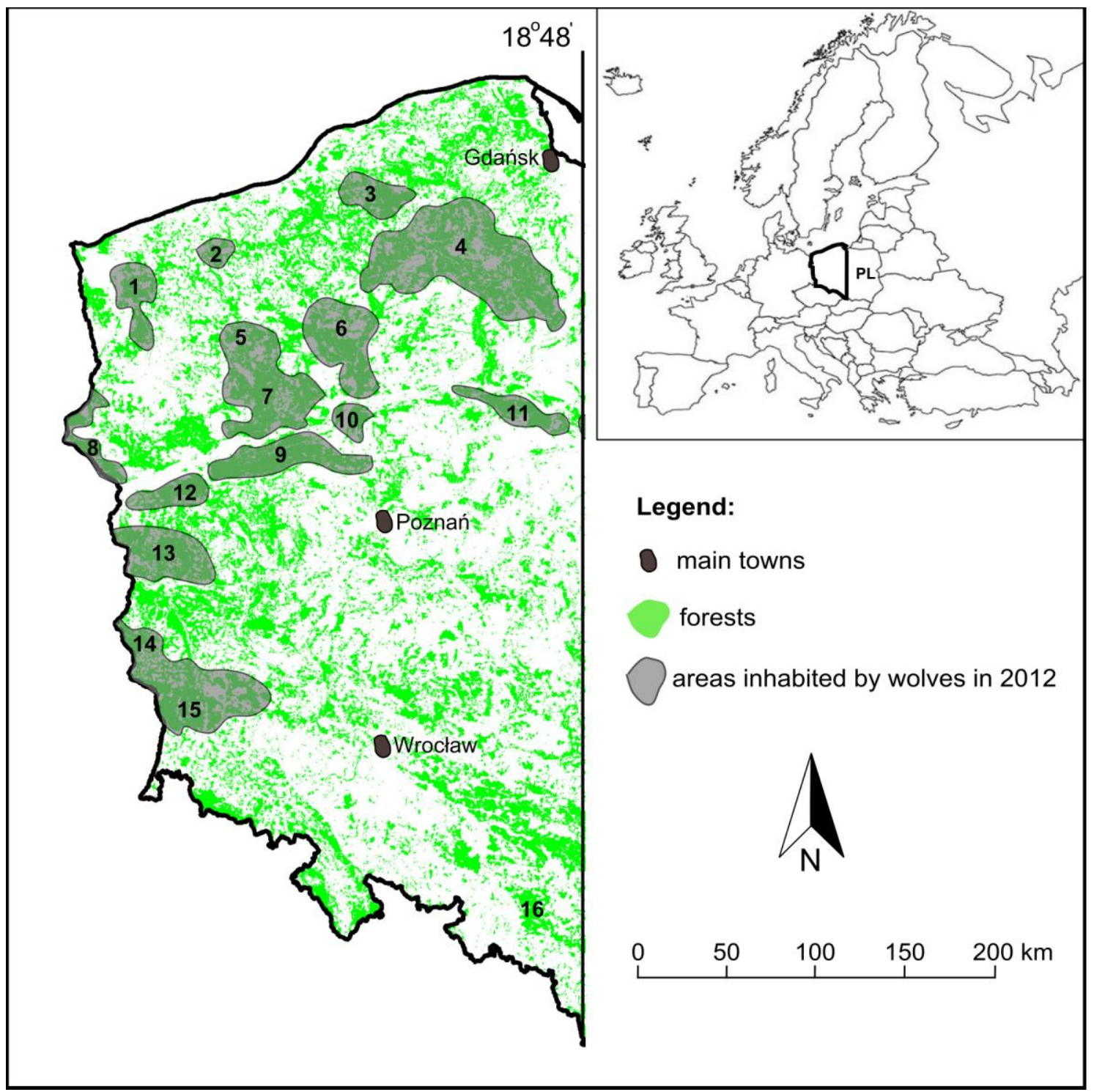

Figure 1. The study area (western Poland). Numbers refer to the IDs of forest tracts (shaded areas) where presence of wolves was reported at least once in 1951-1997: 1-Goleniow Forest;

2 - Ryman Forest, 3 - Slupsk Forest, 4 - Tuchola Forest, 5 -Drawsko Forest, 6 - Walcz

Forest, 7 - Drawa Forest, 8 - Cedynia Forest, 9 - Notec Forest, 10 - Sarbia Forest, 11 Bydgoszcz Forest, 12 - Lubuskie Forest, 13 - Rzepin Forest, 14 - Lubsko Forest, 15 - Lower Silesian Forest, $16-$ Rudy.

These forests are administered by 430 forest districts (so-called "nadleśnictwo"), with an average area of $175 \mathrm{~km}^{2}$. Each forest district is divided into a grid: squares (approx. $500 \times 500 \mathrm{~m}$ ) or rectangles (approx. $300 \times 700 \mathrm{~m}$ ) of 10-35 hectares, which are the basic units for forest management. This grid is especially old and regular in WPL, where the German model of forest management was introduced long before the Second World War. Between compartments there is dense network of logging roads and pathways (3$10 \mathrm{~m}$ wide, mean density $3.9 \mathrm{~km} / \mathrm{km}^{2}$ ). There is also an irregular network of main forest roads (mean $2.5 \mathrm{~km} / \mathrm{km}^{2}$ ), some with a hard surface (mean $0.4 \mathrm{~km} / \mathrm{km}^{2}$ ) (Piekutkin et al., 2015). All forests and other lands (also private properties) in Poland outside of 
national parks and human settlements are divided into about 4,700 hunting grounds with a mean area of 5,400 hectares. These are leased by the Polish government on a longterm basis to ca. 2,500 hunting clubs belonging to the Polish Hunting Association (PHA, with ca. 120,000 members) or are managed by local forest districts (Central Statistical Office, 2016). Most forest roads are closed to public traffic, but hunters from the PHA clubs that rent local hunting grounds can use them without limits. Hunters can also construct numerous hunting towers, feeders, water ponds and bait sites along roads and within forest compartments. The spatial division, dense forest road network and hunting constructions make the lowland forests (especially in WPL) accessible to cars and other vehicles and well-designed to hunt game species.

All wild-living animals, including game species, are state-owned in Poland. Nowadays there are five native species of ungulates in WPL; however, only red deer (Cervus elaphus), roe deer (Capreolus capreolus) and wild boar (Sus scrofa) have abundant populations, while moose (Alces alces) and bison (Bison bonasus) are rare. Locally, alien species, such as fallow deer (Dama dama) and mouflon (Ovis musimon), have been introduced for recreational hunting (Borowik et al., 2013). After the Second World War, red deer - the most important prey for wolves in Poland (Nowak et al., 2005; Jędrzejewski et al., 2012) - were present mainly in western and northern Poland, and were scarce or absent in the eastern part of the country. In the mid 1950s red deer were reintroduced to EPL (Niedziałkowska et al., 2012), and their range and number gradually increased; however, they were still more abundant in the western than in eastern part of the country. According to hunter estimates, mean densities were 4 indiv. $/ 10 \mathrm{~km}^{2}$ (range $2.3-7.1$ ) in WPL, compared with 1.5 indiv. $/ 10 \mathrm{~km}^{2}$ (range $0.4-$ 5.3) in the lowland part of EPL in 1981-2004 (Grabińska, 2007). Even today, abundances of these three ungulate species are higher in WPL than in EPL (Borowik et al., 2013)

The wolf is the only species of large carnivore that has established a substantial population in WPL (Nowak and Mysłajek, 2016), while only single observations of Eurasian lynx (Lynx lynx) have been recorded in this part of country (Niedziałkowska et al., 2006; Nowak et al., 2013).

\section{Data collection and analysis}

We obtained data about wolf presence in the lowland part of WPL for three periods: (1) the wolf eradication period (1951-1974), when wolves were persecuted and killed by all available means (fireguns, poison, traps, removal of litters, hunts with fladry, beaters or $\operatorname{dog} s$ ), on the basis of well managed long-term action organised and financed by the Polish government and supported by the State Forests; (2) hunting management (19751997) when wolves regardless of age and sex where shot with guns by hunters from the PHU, in individual hunts (from concealment or hunting towers), during group hunts with beaters and fladry or driven hunts with dogs, to reduce their number and obtain trophies; and (3) strict protection (1998-2012), when killing wolves was forbidden and culls were permitted only under derogations issued by the Minister of Environment or the General Director for Environmental Protection.

Because wolf censuses performed by hunters can lead to overestimation of wolf population size (Okarma, 1989), we did not attempt to extract from hunting reports the numbers of wolves that occurred annually in WPL between 1951-1997. Instead, we obtained the distribution and number of wolf groups $(\geq 2)$, as well as the mortality of wolves in WPL in years of wolf eradication and hunting management based on all 
available sources, including hunting data, which was used as a source of information about wolf presence, distribution, mortality and reproduction. We compared these compiled data with wolf number and mortality recorded by us between 2001-2012 in WPL (Nowak and Mysłajek, 2016).

We extracted data on wolf occurrence and harvest in WPL for the period 1951-1974 from papers of Kowalski (1953), Sumiński (1975), Wolsan et al. (1992), Buchalczyk (1992), Okarma (1989, 1993), Bobek et al. (1993, 1997), as well as archival reports and applications for wolf bounties from the wolf eradication programme stored in the State Forests Directorate in Szczecinek town. For the period 1975-1997, sources of information were Okarma (1989, 1993), Bereszyński (1998), Bereszyński et al. (2001), hunting surveys and reports about harvested wolves collected by the Research Station of the Polish Hunting Association in Czempiń, database of the Central Statistical Office in Warsaw and the thesis of Treichel and Wessel (1993). For both periods, we obtained additional data from local hunters and foresters. We also used information from articles, reports and tabulations published in 1951-1998 in Polish hunting magazines. The same sources were used to extract the numbers of wolves killed in the whole of Poland in 1954-1997. Data about the number of wolf packs and wolf mortality in WPL for 19982012 were obtained from Jędrzejewski et al. (2002) and Nowak and Mysłajek (2016).

We entered all the collected information from 1951 to 1997 into a database and tagged the recorded wolf locations with geographic coordinates to create digital layers that were later analysed with GIS software (MapInfo Professional 10.5, MapInfo Corp., USA). We attempted to estimate the number of forests occupied by wolves in particular years. To estimate the distribution and minimum number of wolf groups $(\geq 2)$ in WPL we searched for records about the presence (direct observation, tracks) or death of $\geq 2$ wolves in an area, and evidence of wolf reproduction (e.g. the sighting or killing of pregnant or lactating females and pups, found wolf dens, reports about removed litters). We drew a circle with a radius of $8 \mathrm{~km}$ around every recorded wolf reproduction, which is equivalent to an area of about $200 \mathrm{~km}^{2}$ - the average size (MCP95\%) of a wolf territory in Poland (Jędrzejewski et al., 2007, 2008). Evidence of the presence or death of more than one wolf in an area was also enclosed in circles referring to the mean wolf territory size. From hunting reports and applications for wolf bounties we extracted the numbers of wolves shot in various forests during each year.

\section{Results}

After the Second World War, the first wolf reproduction in the lowland part of WPL was recorded in 1951 (the Notec Forest, area no 9, Fig. 1). In 1951-1974 - shortly before, and during the wolf eradication period - wolf presence was reported in up to 4 forest tracts per year (mean 1.7, $\mathrm{SE}=1.1$ ). They were primarily loners or nonreproductive pairs. Moreover, even though these forests are large enough to host from 3 to 7 wolf packs, there was never any more than one wolf group consisting of $\geq 2$ wolves in each. During 1956-1974 (a period from which more detailed data are available) the number of wolf groups in WPL varied annually from 0 to 3 (Fig. 3). In this period, wolf groups were recorded 14 times (on average 0.7 wolf groups/year, $\mathrm{SE}=0.65$ ), while reproduction was recorded only 6 times (on average 0.3 litters/year, $\mathrm{SE}=0.45$ ). 

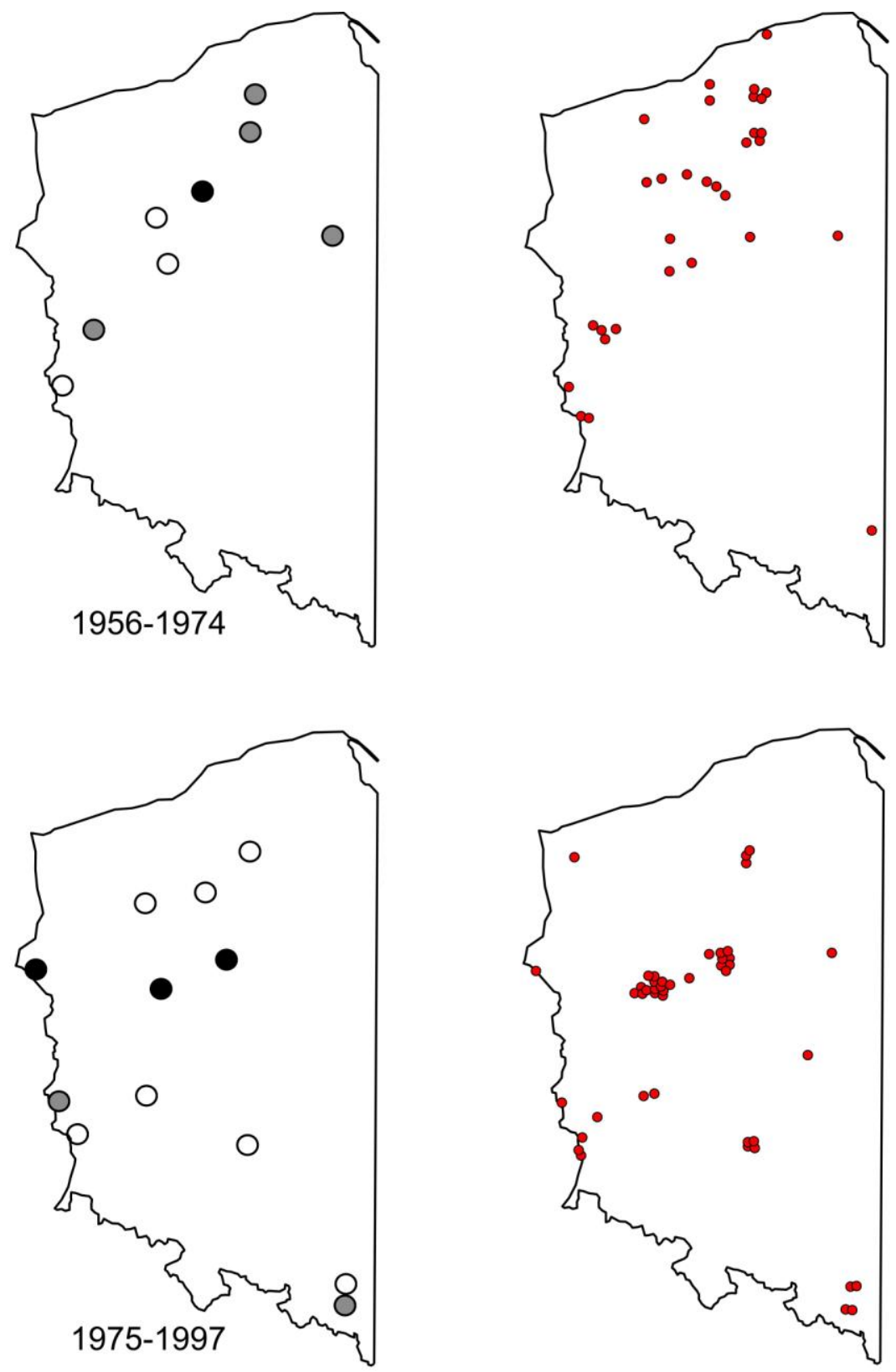

- Wolf groups with reproduction confirmed in at least two years

- Wolf groups with reproduction confirmed in only one year

O Wolf groups without confirmed reproduction

\section{- Locations of killed wolves}

Figure 2. Distribution of wolf groups and wolves killed in the periods of wolf persecution (1956-1974), and hunting management (1975-1997). 


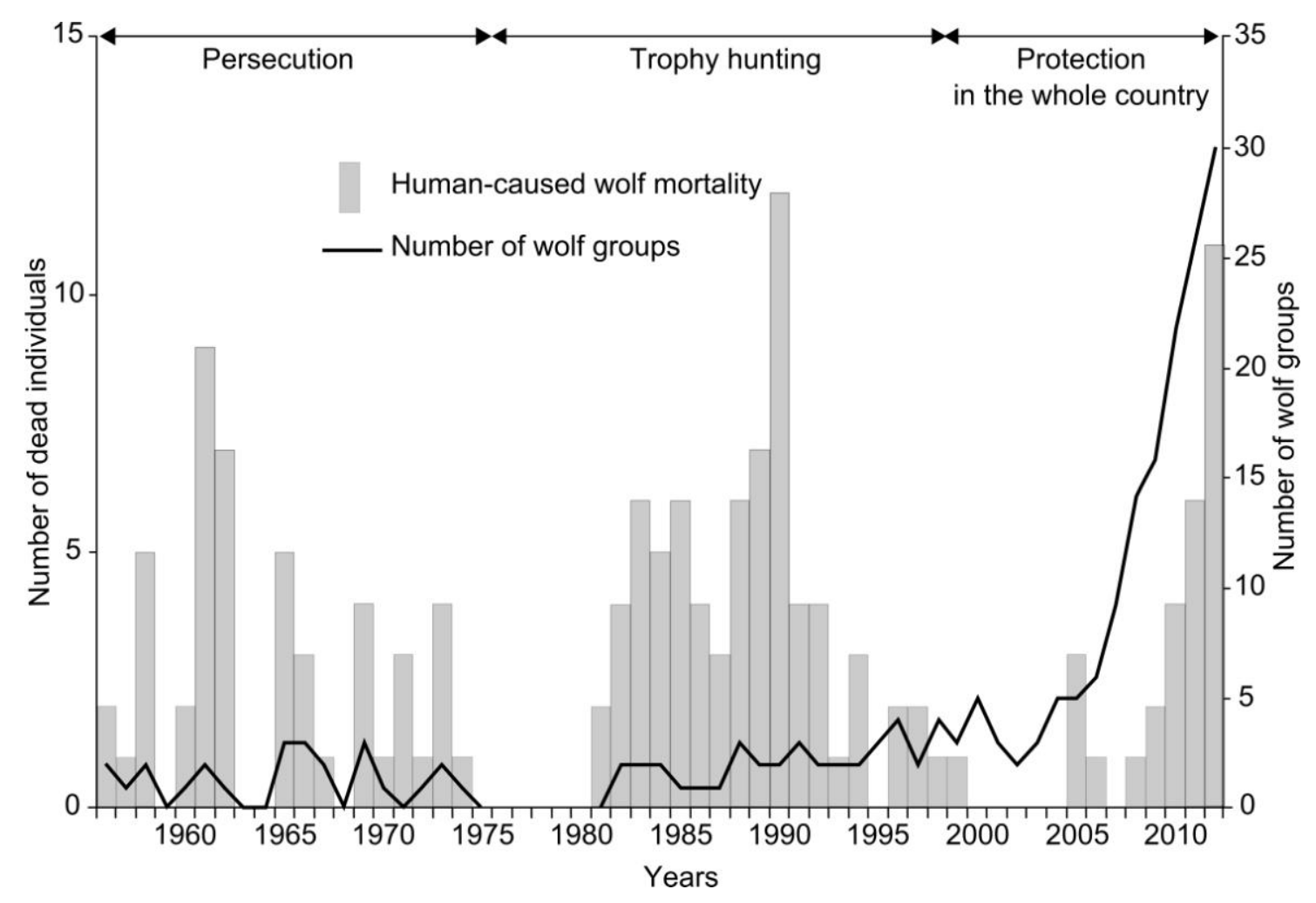

Figure 3. Number of wolf groups and dead wolves in western Poland under various management regimes, 1956-2012.

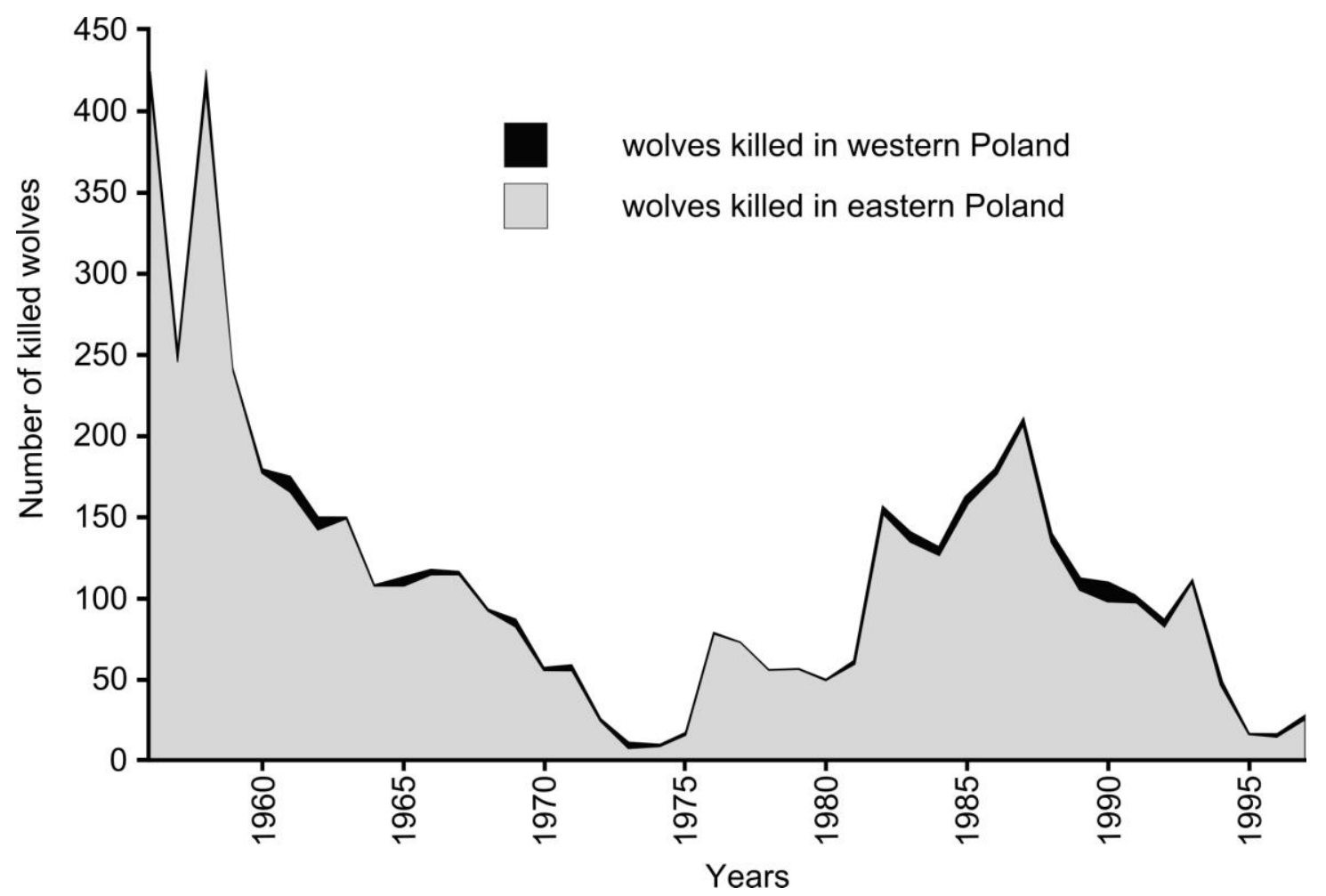

Figure 4. Number of wolves killed by hunters in eastern and western Poland in 1956-1997. 
Most of the groups bred only once and were then eradicated. In one area (the Walcz Forest, area no 6 in Fig. 1), wolf presence was confirmed over four consecutive years (1965-1968); wolves reproduced there twice (Fig. 2), but with a four year delay in between. Non-reproductive pairs or loners were killed soon after being detected in WPL. In total, in the whole lowland part of WPL, at least 49 wolves (including 39 adults) were exterminated between 1956 and1974, on average 2.6 wolves/year (range 09, $\mathrm{SE}=0.58)$.

Among 49 killed individuals, gender was recorded for 22 males and 10 females, and the sex ratio was greatly male-biased compared to normal $\left(\chi^{2}=7.49, \mathrm{df}=1, \mathrm{p}=0.01\right)$. The highest number of wolves killed was in 1961 (9 animals) and 1962 (7 animals) (Fig. 3). This was primarily the eradication of resident breeding packs in the Tuchola and Walcz Forests (area no 4 and 6 in Fig. 1, Fig. 2). During the wolf eradication period in EPL the highest numbers of wolves killed were 425 (in 1956 and 1958) (Fig. 4). The last wolf (a yearling - the only survivor from a pack) in WPL was shot in early 1975 in the Rzepin Forest (area no 13 in Fig. 1).

From 1975 to 1980 only a few vagrants were spotted in WPL. In 1981 two wolves were shot by hunters in two places distant from each other, while in 1982 one animal was hit by a car, three wolves were killed by hunters, and the first breeding group was recorded close to the Polish-German border (Lubsko Forest, area no 14, Fig. 1 and 2). Between 1981 and 1997 wolves (loners or groups) were present in one to four forests per year (mean 3.1, SE=0.28), but no more than one group occurred per forest tract. Annually in WPL, there were on average 1.6 groups (range 0-4, SE=0.24) present, but with less than one reproduction (range 0-2, SE=0.17). Most of these groups did not breed or bred only once and were harvested in the first year after detection. Longer persistence (from 2 to 8 years) was recorded in only three packs. The longest periods of successive reproduction in the same pack territory were 7 (1984-1990, Notec Forest, area no 9 in Fig. 1) and 5 years (1987-1992, Sarbia Forest, area no 10 in Fig. 1, Fig. 2). From 1975 until 1997, in total 70 wolves were harvested in WPL, on average 3.0 wolves per year (range 0-12, SE=0.63) (Fig. 3). In eastern Poland, the highest number of wolves killed over one hunting season was 208 individuals (in 1987), while in WPL it was 12 (in 1990) (Fig. 4). Wolves in WPL were mainly shot in the Notec, and Sarbia forests (areas no 9 and 10, Fig. 1), where most individuals from two breeding groups were removed (Fig. 2). Among 20 adult wolves of known sex that were killed over several years in these two adjacent forests, there were 14 males and 6 females $(70 \%$ and $30 \%$ respectively). In the whole of WPL among 32 harvested wolves of known sex there were 25 males $(78 \%)$ and 7 females (22\%), which greatly differs from the normal sex ratio $\left(\chi^{2}=17.014, \mathrm{df}=1, \mathrm{p}<0.001\right)$. Although wolves have been protected in WPL from 1995, at least two individuals were shot illegally in the region up to 1998.

The mean annual number of wolves killed by humans during the periods of eradication (1956-1974) and hunting management (1975-1997) did not differ (MannWhitney U-test, $\mathrm{U}=205, \mathrm{n}_{1}=19, \mathrm{n}_{2}=23$, NS).

In 1998-2001 the number of wolf groups in WPL fluctuated between 3 and 5, but over the next 10 years this increased to 30 groups by winter 2012/2013. The number of forest tracts inhabited by wolves increased from 4 in 2002 to 14 in 2012. During this period, at least 28 cases of wolf mortality were recorded (Fig. 3), 65\% were killed by vehicles, $25 \%$ were poached, $7 \%$ died of natural causes and the reasons for rest of the mortality remains unknown. The sex ratio of dead individuals (52\% males and $48 \%$ females) did not deviate from 1:1 ratio. 


\section{Discussion}

Our analysis of historical data revealed that there was no substantial difference in the population status of wolves in WPL during the wolf eradication (1956-1974) and hunting management period (1975-1997): in both periods wolf groups in WPL were scarce, from 0 to 3 , and from 0 to 4 groups annually, respectively, and wolves rarely reproduced. In contrast, in EPL wolves were abundant most of the time, which is strongly confirmed by the high wolf harvests (ca. 3,300 in 1956-1974 and ca. 2,080 in 1975-1997) in this region (Sumiński 1975; compiled data of the Polish Central Statistical Office and the Research Station of the Polish Hunting Association). In 1998 wolves became strictly protected throughout Poland, and after a delay of several years they started to re-settle WPL with a high rate of population growth, reaching 30 groups in 2012 (Nowak and Mysłajek, 2016).

After the decline of the wolf population to about 60 individuals in 1972, the inclusion of the wolf on the game species list in 1975 (with a four month closed season widely introduced at the end of 1981) was expected by scientists and hunters to be the best way to extend the range and number of this predator throughout Poland (Sumiński, 1973, 1975). However, this only occurred in EPL and the Carpathian Mountains (Okarma, 1989, 1993; Jędrzejewska et al., 1996). There was no significant growth of the wolf population in WPL during the hunting management period. The large disparity between the numbers of wolves harvested in the eastern (together with the Carpathians) and western parts of the country (Fig. 4.) shows that wolves were much more abundant in EPL even though they were subjected to immense human pressure. At that time the wolf skull and skin were valuable trophies for hunters throughout the country (Okarma, 1993; Pielowski et. al., 1993).

The deliberate persecution driven by human hostility and fear, competition with hunters for game animals, and damage to livestock resulted in the wolf disappearance from most of western and central Europe in the $19^{\text {th }}$ and $20^{\text {th }}$ centuries (Boitani, 2003). However, in many regions, such as south-western Europe, wolf decline was also mediated by substantial deterioration of natural habitats including deforestation, habitats fragmentation and isolation, as well as a rapid decline in wild ungulates (Meriggi et al., 1991; Boitaini, 1992; Fernández and de Azua, 2010). Shortly after the Second World War, red deer were present in WPL, and extinct in EPL. Translocation of over one thousand red deer in the mid 1950s from western to eastern Poland allowed successful recovery of the species (Niedziałkowska et al., 2012). However, densities of red deer were still three-fold higher in western than in eastern Poland (mean 4 indiv./10 $\mathrm{km}^{2}$ in WPL versus 1.5 indiv./10 $\mathrm{km}^{2}$ in EPL, in 1981-2004), as were the densities of two other native wild ungulates (roe deer and wild boar) (Pucek et al., 1975; Pielowski et al., 1993; Grabińska, 2007) - together these species comprise most of the wolf diet in Poland (Jędrzejewski et al., 2012). Because hunter surveys underestimate numbers of ungulates, the actual densities in WPL were most likely much higher than stated in the official data (Pucek et al., 1975). This was confirmed in studies using different survey methods, including chase and nocturnal counts in spotlights, to count red deer in two forests of WPL. These showed that densities of this ungulate were extremely high, varying from 61 to 136 indiv/10 $\mathrm{km}^{2}$ (Pucek et al., 1975; Dieciołowski et al., 1995). The large number of red deer harvested annually in WPL (mean 10.6 indiv./10 km in 1991) also indicates that densities of this potential wolf prey were high in this region (Pielowski et al., 1993). These disparities between WPL and EPL are still valid today 
(Borowik et al., 2013). Thus, a shortage of food was not a reason for the scarcity of wolves in WPL during the hunting management period, between 1975 and 1998.

Recently the habitat loss, high human density and the dense network of public roads are widely considered as factors negatively influencing animal persistence and recovery across the world (Karlsson et al., 2007; Fahrig and Litwinski, 2008; Shepard et al., 2008; Huck et al., 2010, 2011). Yet forest cover increased across the whole of Poland after the Second World War, from 21\% in 1946 to $29 \%$ today, but the increase was most rapid before 1970 (up to 27\%). Forest cover has always been higher in WPL than in EPL (Central Statistical Office, 2016). Although human density in WPL increased from 64 in 1950, to 108 inhabitants $/ \mathrm{km}^{2}$ in 2012, this population growth affected mostly towns. In contrast, densities in rural areas remained stable over this period (mean 42 inhabitants $/ \mathrm{km}^{2}$, range 37-44), and are lower than figures for the whole of Poland (mean 51 inhabitants $/ \mathrm{km}^{2}$, range 50-52) (Gawryszewski, 2005; Central Statistical Office, 2012).

The density of public hard-surface roads which is considered as limiting the wolf presence is $>0.6 \mathrm{~km} / \mathrm{km}^{2}$ (Thiel, 1985). This allows human access to wolf habitats and increases road mortality (Mech, 1988; Mech et al., 1989; Jędrzejewski et al., 2004, 2005). Nevertheless, an analysis of variables connected with wolf distribution in Galicia (N Spain) revealed that wolves, when legally protected and with free access to safe refuges, can survive in areas with remarkably high densities of paved roads (up to 3.7 $\mathrm{km} / \mathrm{km}^{2}$ ) (Llaneza et al., 2012). In the whole of Poland, the density of hard-surface roads increased from $0.4 \mathrm{~km} / \mathrm{km}^{2}$ in 1950 to $0.8 \mathrm{~km} / \mathrm{km}^{2}$ in 1995 . Moreover, during the wolf recovery period (2001-2012) road density grew to $0.9 \mathrm{~km} / \mathrm{km}^{2}$ (Central Statistical Office, 2012, 2015).

This shows that a lack of suitable habitats, human density and the dense public road network could not be a reason for the scarcity of wolves in WPL during the hunting management period. Even now, after decades of human infrastructure development, a habitat suitability model has revealed that there are plenty of good habitats for wolves in WPL ( $39,000 \mathrm{~km}^{2}, 63 \%$ of all habitats available in the country), which could host up to 790 wolves (Jędrzejewski et al., 2008). These habitats are quite well connected by network of ecological corridors which allow dispersal of wolves between EPL and WPL, in both directions (Jędrzejewski et al., 2009; Schede et al., 2010; Huck et al., 2010, 2011).

Therefore the most important factors contributing to the rarity of wolves in WPL between 1975-1997 were as follows: the high intensity hunting efforts both in eastern and western Poland; a large distance to the continuous wolf range in EPL and the dense network of forest roads in WPL allowing easy access of hunters to wolf refuges. Analyses of the hunting database from 1981-1997 revealed that in WPL almost all wolves detected in hunting grounds during winter censuses were included into hunting management plans and harvested. Wolves were also introduced to hunting management plans 'in advance' or shot without planning (Okarma, 1993). Driven hunts, which are one of the most common methods to hunt ungulates in autumn and winter in Poland, were also used as a good opportunity to spot and kill wolves accidentally scared from hiding by beaters.

The number of wolves annually killed in WPL during the wolf eradication (19561974) and hunting management (1975-1997) periods was similar (2.6 killed wolves/year and 3.0 killed wolves/year, respectively). In cases when groups of wolves were discovered, hunters frequently shot several animals, including breeding pairs, which 
probably led to pack dissolution (Brainerd et al., 2008; Borg et al., 2015). In the source wolf population in EPL, recreational hunting reached a peak of 208 harvested individuals in 1987, and then dropped to 28 in 1997 due to the consequent decline in the number of wolves in the country (Okarma, 1993; data of the Polish Central Statistical Office). This enormous harvest most probably hampered long-distance dispersal of wolves to the west. Together with the killing of all detected newcomers and the destroying of newly settled packs, this impeded wolf recolonisation in WPL. Similarly, in Finland and Sweden legal hunting or persecution of wolves in source populations or in zones between two protected populations has caused immigration of new individuals to be extremely rare, negatively influencing the recovery process (Liberg et al., 2005; Kojola et al., 2009; Jansson et al., 2012).

Although wolves are known as persistent vagrants, the mean dispersal distance recorded both in Europe and North America is approximately $100 \mathrm{~km}$ (Boyd and Pletscher, 1999; Kojola et al., 2009) and most dispersers (ca. 80\%) do not travel further than $200 \mathrm{~km}$. Only a few (7\%) wolves travel over $300 \mathrm{~km}$, and such long movements are mostly undertaken by males (75\%; Linnell et al., 2005). The mean straight distance from the source population in EPL to habitats suitable for wolves in WPL was $376 \pm$ $106.5 \mathrm{~km}$ (Nowak and Mysłajek, 2016). A comparison of historical genetic variability of Scandinavian wolf populations suggested long-distance dispersal in the south of the Scandinavian Peninsula is male-biased (Flagstadt et al., 2003). Among wolves harvested in WPL during the hunting management period there was a high prevalence of males (78\% in our data, and 81.6\% according to Bobek et al., 1993), which suggests a scarcity of females in local populations. The limited number of females would have reduced the probability of finding mates in the low wolf densities of WPL, which together with the high mortality caused by intensive hunting led the local populations to extinction due to Allee effects (Wabakken et al., 2001; Stenglein and van Deelen, 2016).

Logging roads and unforested pathways together with the irregular network of main forest roads in the forests of WPL (mean density $3.9 \mathrm{~km} / \mathrm{km}^{2}$ and $2.5 \mathrm{~km} / \mathrm{km}^{2}$, respectively) divide even the largest woodlands into a fine rectangular grid of spatial compartments $(500 \times 500 \mathrm{~m}$ or $700 \times 350 \mathrm{~m})$ leaving no safe refuges for wolves. Most of these roads are in a straight-line, which helps to see and shoot animals over long distances. Driving or hiking along these roads enables detection of wolves that use roads regularly and leave their visible tracks and scent marks (Zub et al., 2003; Nowak and Mysłajek, 2016). It was particularly easy when snow cover was present, which was frequent in the $20^{\text {th }}$ century. In summer finding wolf dens, rendezvous sites and resting sites was facilitated by good visibility in simplified pine monocultures, the short distance from the nearest forest road to the central point of the forest compartment $(<350 \mathrm{~m})$, and sandy road surfaces where tracks and scats are well visible. It helped to find wolves at the onset of hunting season (August $1^{\text {st }}$ ) and then during whole autumn or when snow was absent in winter. Forest roads also enabled hunters to build and use well insulated hunting towers located in front of baiting places, and bring large rolls with fladry when wolves were detected in their daily resting places after snow-tracking along forest roads. Wolf family groups then were surrounded with fladry in the forest compartments scared by beaters and shot by hunters (Okarma and Jędrzejwski, 1997). Concluding, thanks to the dense network of forest roads in WPL the possibility of detection and efficiency of hunts on wolves were very high. 
Our study has shown that subpopulations of wolves living far from a source of immigrants, in areas heavily altered by humans, with good access to the most distant refuges due to a well developed road network should be managed with great care. At the edges of the species' range recreational hunting may have similar effects to intentional eradication, thus cannot be applied without proper analysis of population viability and connectivity with other subpopulations. Similarly, severe wolf hunting in areas that are the only source of immigrants can negatively influence the number and survival of the source-dependent populations. This recommendation is of particular importance in a time when wolves are expanding into regions from which they were extirpated centuries ago, to managed forests heavily transformed by humans (Chapron et al., 2014), and where local subpopulations still depend on immigration from other areas.

Acknowledgements. Research done within this project was supported by the International Fund for Animal Welfare (USA), EuroNatur (Germany), Wolves and Humans Foundation (UK), and the statutory budget of the Association for Nature "Wolf" (Poland). RWM was funded by the National Science Centre (Poland) grant number DEC-2014/12/S/NZ8/00624. We thank K. Weksej (retired) from the Regional Directorate of State Forests in Szczecinek and M. Panek from the Research Station of the Polish Hunting Association for providing data on wolf mortality. We thank T. Diserens for the linguistic advice and Anonymous Reviewers for suggestions that led to a greatly improved manuscript.

\section{REFERENCES}

[1] Ballard, W.B., Ayres, L.A., Krausman, P.R., Reed, D.J., Fancy, S.G. (1997): Ecology of wolves in relations to a migratory caribou herd in northwest Alaska. - Wildlife Monographs 135: 1-47.

[2] Bereszyński, A. (1998): The wolf (Canis lupus Linnaeus, 1758) in Poland and its protection. - Wydawnictwo AR w Poznaniu, Poznań (in Polish).

[3] Bereszyński, A., Kala, B., Więckowski, J. (2001): Occurrence of the wolf (Canis lupus Linnaeus, 1758) in Western Poland. - Roczniki Akademii Rolniczej w Poznaniu 344, Zootechnika 53: 3-24 (in Polish).

[4] Bobek, B., Frąckowiak, W., Goździewski, J., Harna, G., Kasperczyk, B., Merta, D., Nowicki, P., Płodzień, K., Wiśniowska, L. (1997): Large carnivores in Poland: overprotection or sustainable use? - Journal of Wildlife Research 2: 282-295.

[5] Bobek, B., Kosobucka, M., Perzanowski, K., Plodzien, K. (1993): Distribution and wolf numbers in Poland. - In: Promberger, C., Schröder, W. (eds) Wolves in Europe: Status and perspectives. Munich Wildlife Society, Ettal.

[6] Boitaini, L. (1992): Wolf research and conservation in Italy. - Biological Conservation 61: 125-132.

[7] Boitani, L. (2003): Wolf conservation and recovery. - In: Mech, L.D., Boitani, L. (eds) Wolves. Behavior, ecology, and conservation. University of Chicago Press, ChicagoLondon.

[8] Borg, B.L., Brainerd, S.M., Meier, T.J., Prugh, L.R. (2015): Impacts of breeder loss on social structure, reproduction and population growth in a social canid. - Journal of Animal Ecology 84: 177-187.

[9] Borowik, T., Cornulier, T., Jędrzejewska, B. (2013): Environmental factors shaping ungulate abundances in Poland. - Acta Theriologica 58: 403-413.

[10] Boyd, D.K., Pletscher, D.H. (1999): Characteristics of dispersal in a colonizing wolf population in the Central Rocky Mountains. - Journal of Wildlife Management 63: 10941108.

[11] Brainerd, S.M., Andrén, H., Bangs, E.E., Bradley, E.H., Fontaine, J.A., Hall, W., Iliopoulos, Y., Jimenez, M.D., Jozwiak, E.A., Liberg, O., Mack, C.M., Meier, T.J., 
Niemeyer, C.C., Pedersen, H.C., Sand, H., Schultz, R.N., Smith, D.W., Wabakken, P., Wydeven, A.P. (2008): The effects of breeder loss on wolves. - Journal of Wildlife Management 72: 89-98.

[12] Bryan, H. M., Smits, J. E. G., Korenm L., Paquet, P.C., Wynne-Edwards, K.E., Musiani, M. (2015): Heavily hunted wolves have higher stress and reproductive steroids than wolves with lower hunting pressure. - Functional Ecology 29: 347-356.

[13] Buchalczyk, T. (1992): Canis lupus. - In: Głowaciński, Z. (ed.) Polish Red Data Book of Animals. Państwowe Wydawnictwo Rolnicze i Leśne, Warszawa (in Polish).

[14] Central Statistical Office. (2012): Statistical Yearbook of the Regions - Poland 2012. Central Statistical Office, Warsaw (in Polish).

[15] Central Statistical Office. (2013): Statistical Yearbook of the Republic of Poland 2013. Central Statistical Office, Warsaw (in Polish).

[16] Central Statistical Office. (2014): Poland 1989-2014. - Central Statistical Office, Warsaw (in Polish).

[17] Central Statistical Office. (2015): Road transport in Poland in the years 2012, 2013. Central Statistical Office, Warsaw (in Polish).

[18] Central Statistical Office. (2016): Forestry 2016. - Central Statistical Office, Warsaw (in Polish).

[19] Chapron, G., Kaczensky, P., Linnell, J. D. C., von Arx, M., Huber, D., Andrén, H., López-Bao, J.V., Adamec, M., Álvares, F., Anders, O., Balčiauskas, L., Balys, V., Bedő, P., Bego, F., Blanco, J. C., Breitenmoser, U., Brøseth, H., Bufka, L., Bunikyte, R., Ciucci, P., Dutsov, A., Engleder, T., Fuxjäger, C., Groff, C., Holmala, K., Hoxha, B., Iliopoulos, Y., Ionescu, O., Jeremić, J., Jerina, K., Kluth, G., Knauer, F., Kojola, I., Kos, I., Krofel, M., Kubala, J., Kunovac, S., Kusak, J., Kutal, M., Liberg, O., Majić, A., Männil, P., Manz, R., Marboutin, E., Marucco, F., Melovski, D., Mersini, K., Mertzanis, Y., Mysłajek, R. W., Nowak, S., Odden, J., Ozolins, J., Palomero, G., Paunović, M., Persson, J., Potočnik, H., Quenette, P. -Y., Rauer, G., Reinhardt, I., Rigg, R., Ryser, A., Salvatori, V., Skrbinšek, T., Stojanov, A., Swenson, J. E., Szemethy, L., Trajçe, A., TsingarskaSedefcheva, E., Ván̆a, M., Veeroja, R., Wabakken, P., Wölfl, M., Wölfl, S., Zimmermann, F., Zlatanova, D., Boitani, L. (2014): Recovery of large carnivores in Europe's modern human-dominated landscapes. - Science 346: 1517-1519.

[20] Czarnomska, S.D., Jędrzejewska, B., Borowik, T., Niedziałkowska, M., Stronen, A.V., Nowak, S., Mysłajek, R.W., Okarma, H., Konopiński, M., Pilot, M., Śmietana, W., Caniglia, R., Fabbri, E., Randi, E., Pertoldi, C., Jędrzejewski, W. (2013): Concordant mitochondrial and microsatellite DNA structuring between Polish lowland and Carpathian Mountain wolves. - Conservation Genetics 14: 573-588.

[21] Duffield, J.W., Neher, C.J., Patterson, D.A. (2008): Wolf recovery in Yellowstone: park visitor attitudes, expenditures, and economic impacts. - Yellowstone Science 25: 13-19.

[22] Dzięciołowski, R., Goszczyński, J., Wasilewski, M., Babińska-Werka, J. (1995): Numbers of red deer in the Słowiński National Park, Poland. - Acta Theriologica 40: 4551.

[23] Fahrig, L., Rytwinski, T. (2009): Effects of roads on animal abundance: an empirical review and synthesis. - Ecology and Society 14(1): 21.

[24] Fernández, J.M., de Azua, N.R. (2010): Historical dynamics of a declining wolf population: persecution vs. prey reduction. - European Journal of Wildlife Research 56: 169-179.

[25] Flagstadt, Ø., Walker, C.W., Vilá, C., Sundqvist, A.-K., Fernholm, B., Hufthammer, A.K., Wiig, Ø., Koyola, I., Ellegren, H. (2003): Two centuries of the Scandinavian wolf population: patterns of genetic variability and migration during an era of dramatic decline. - Molecular Ecology 12: 869-880.

[26] Fuller, T.K. (1989): Population dynamics of wolves in north-central Minnesota. American Midland Naturalist 121: 184-188. 
[27] Fuller, T.K., Mech, L.D., Cochrane, J.F. (2003): Wolf population dynamics. - In: Mech, L.D., Boitani, L. (eds) Wolves. Behavior, ecology, and conservation. University of Chicago Press, Chicago-London.

[28] Gawryszewski, A. (2005): The population of Poland in the 20th century. - Instytut Geografii i Przestrzennego Zagospodarowania im. Stanisława Leszczyckiego PAN, Warszawa.

[29] Grabińska, B. (2007): Spatial and temporal changeability of game mammals distribution in Poland. - Instytut Geografii i Przestrzennego Zagospodarowania im. Stanisława Leszczyckiego PAN, Warszawa.

[30] Hayes, R.D., Harestad, A.S. (2000): Demography of a recovering wolf population in the Yukon. - Canadian Journal of Zoology 78: 36-48.

[31] Huck, M., Jędrzejewski, W., Borowik, T., Miłosz-Cielma, M., Schmidt, K., Jędrzejewska, B., Nowak, S., Mysłajek, R.W. (2010): Habitat suitability, corridors and dispersal barriers for large carnivores in Poland. - Acta Theriologica 55: 177-192.

[32] Huck, M., Jędrzejewski, W., Borowik, T., Jędrzejewska, B., Nowak, S., Mysłajek, R.W. (2011): Analyses of least cost paths for determining effects of habitat types on landscape permeability: wolves in Poland. - Acta Theriologica 56: 91-101.

[33] Jansson, E., Ruokonen, M., Kojola, I., Aspi, J. (2012): Rise and fall of a wolf population: genetic diversity and structure during recovery, rapid expansion and drastic decline. Molecular Ecology 21: 5178-5193.

[34] Jędrzejewska, B., Jędrzejewski, W., Bunevich, A. N., Miłkowski, L., Okarma, H. (1996): Population dynamics of wolves Canis lupus in Białowieża Primeval Forest (Poland and Bielarus) in relation to hunting by humans, 1847-1993. - Mammal Review 26: 103-126.

[35] Jędrzejewski, W., Nowak, S., Schmidt, K., Jędrzejewska, B. (2002): The wolf and the lynx in Poland - results of a census conducted in 2001. - Kosmos 51: 491-499 (in Polish).

[36] Jędrzejewski, W., Niedziałkowska, M., Nowak, S., Jędrzejewska, B. (2004): Habitat variables associated with wolf (Canis lupus) distribution and abundance in northern Poland. - Diversity and Distributions 10: 225-233.

[37] Jędrzejewski, W., Niedziałkowska, M., Mysłajek, R.W., Nowak, S., Jędrzejewska, B. (2005): Habitat selection by wolves Canis lupus in the uplands and mountains of southern Poland. - Acta Theriologica 50: 417-428.

[38] Jędrzejewski, W., Schmidt, K., Theuerkauf, J., Jędrzejewska, B., Kowalczyk, R. (2007): Territory size of wolves Canis lupus: linking local (Białowieża Primeval Forest, Poland) and Holarctic-scale patterns. - Ecography 30: 66-76.

[39] Jędrzejewski, W., Jędrzejewska, B., Zawadzka, B., Borowik, T., Nowak, S., Mysłajek, R.W. (2008): Habitat suitability model for Polish wolves Canis lupus based on long-term national census. - Animal Conservation 11: 377-390.

[40] Jędrzejewski, W., Nowak, S., Kurek, R., Mysłajek, R.W., Stachura, K., Zawadzka, B., Pchałek, M. (2009): Animals and roads. Methods of mitigating the negative impact of roads on wildlife. - Mammal Research Institute Polish Academy of Sciences, Białowieża.

[41] Jędrzejewski, W., Niedziałkowska, M., Hayward, M.W., Goszczyński, J., Jędrzejewska, B., Borowik, T., Bartoń, K.A., Nowak, S., Harmuszkiewicz, J., Juszczyk, A., Kałamarz, T., Kloch, A., Koniuch, J., Kotiuk, K., Mysłajek, R.W., Nędzyńska, M., Olczyk, A., Teleon, M., Wojtulewicz, M. (2012): Prey choice and diet of wolves related to ungulate communities and wolf subpopulations in Poland. - Journal of Mammalogy 93: 14801492.

[42] Karlsson, J., Brøseth, H., Sand, H., Andrén, H. (2007): Predicting occurrence of wolf territories in Scandinavia. - Journal of Zoology 272: 276-283.

[43] Kojola, I., Kaartinen, S., Hakal, A., Heikkinen, S., Voipio, H.-M. (2009): Dispersal behaviour and the connectivity between wolf populations in Northern Europe. - Journal of Wildlife Management 73: 309-313. 
[44] Kowalski, Z. 1953. The wolf and its eradication. - Państwowe Wydawnictwo Rolnicze i Leśne, Warszawa (in Polish).

[45] Kuijper, D.P.J., Bubnicki, J.W., Churski, M., Mols, B., van Hooft, P. (2015): Context dependence of risk effects: wolves and tree logs create patches of fear in an old-growth forest. - Behavioural Ecology 26: 1558-1568.

[46] Larivière, S., Jolicoeur, H., Crête, M. (2000): Status and conservation of the gray wolf (Canis lupus) in wildlife reserves of Quèbec. - Biological Conservation 94: 143-151.

[47] Liberg, O., Andrén, H., Pedersen, H.-C., Sand, H., Sejberg, D., Wabakken, P., Åkesson, M., Bensch, S. (2005): Severe inbreeding depression in a wild wolf (Canis lupus) population. - Biology Letters 1: 17-20.

[48] Linnell, J.D.C., Brøseth, H., Solberg, E.J., Brainerd, S.M. (2005): The origins of the southern Scandinavian wolf Canis lupus population: potential for natural immigration in relation to dispersal distances, geography and Baltic ice. - Wildlife Biology 11: 383-391.

[49] Llaneza, L., López-Bao, J.V., Sazatornil, V. (2012): Insights into wolf presence in human-dominated landscapes: the relative role of food availability, humans and landscape attributes. - Diversity and Distributions 18: 459-469.

[50] Mech, L.D. (1989): Wolf population survival in an area of high road density. - American Midland Naturalist 121: 387-338.

[51] Mech, L.D. (1995): The challenge and opportunity of recovering wolf populations. Conservation Biology 9: 270-278.

[52] Mech, L.D., Fritts, S.H., Radde, G.L., Paul, W.J. (1988): Wolf distribution and road density in Minnesota. - Wildlife Society Bulletin 16: 85-87.

[53] Meriggi, A., Rosa, P., Brangi, A., Matteucci, C. (1991): Habitat use and diet of the wolf in northern Italy. - Acta Theriologica 36: 141-151.

[54] Mysłajek, R.W., Nowak, S. (2015): Not an easy road to success: the history of exploitation and restoration of the wolf population in Poland after World War II. - In: Masius, M., Sprenger, J. (eds) A fairytale in question: Historical interactions between humans and wolves. White Horse Press, Cambridge.

[55] Niedziałkowska, M., Jędrzejewski, W., Mysłajek, R.W., Nowak, S., Jędrzejewska, B., Schmidt, K. (2006): Environmental correlates of Eurasian lynx occurrence in Poland Large scale census and GIS mapping. - Biological Conservation 133: 63-69.

[56] Nowak, S., Kasprzak, A., Mysłajek, R.W., Tomczak, P. (2013): Records of the Eurasian lynx Lynx lynx in the Notecka forest. - Przegląd Przyrodniczy 24: 84-86 (in Polish).

[57] Nowak, S., Mysłajek, R.W. (2016): Wolf recovery and population dynamics in Western Poland, 2001-2012. - Mammal Research 61: 83-98.

[58] Nowak, S., Mysłajek, R.W., Jędrzejewska, B. (2005): Patterns of wolf Canis lupus predation on wild and domestic ungulates in the Western Carpathian Mountains (S Poland). - Acta Theriologica 50: 263-276.

[59] Nowak, S., Mysłajek, R.W., Jędrzejewska, B. (2008): Density and demography of wolf, Canis lupus population in the western-most part of the Polish Carpathian Mountains, 1996-2003. - Folia Zoologica 57: 392-402.

[60] Nowak, S., Mysłajek, R.W., Kłosińska, A., Gabryś, G. (2011): Diet and prey selection of wolves Canis lupus recolonising Western and Central Poland. - Mammalian Biology 76: 709-715.

[61] Okarma, H. (1989): Distribution and numbers of wolves in Poland. - Acta Theriologica 34: 497-503.

[62] Okarma, H. (1993): Status and management of the wolf in Poland. - Biological Conservation 66: 153-158.

[63] Okarma, H., Jędrzejewski, W. (1997): Livetrapping wolves with nets. - Wildlife Society Bulletin 25: 78-82.

[64] Piekutin, J., Kłapeć, B., Orzechowski, M. (2015): Density of forest road network economic point of view. - Sylwan 159: 179-187 (in Polish). 
[65] Pielowski, Z., Kamieniarz, R., Panek, M. (1993): Report about game animals in Poland. Państwowa Inspekcja Ochrony Środowiska, Warszawa (in Polish).

[66] Pletscher, D.H., Ream, R.R., Boyd, D.K., Fairchild, M.W., Kunkel, K.E. (1997): Population dynamics of a recolonizing wolf population. - Journal of Wildlife Management 61: 459-465.

[67] Pucek, Z., Bobek, B., Łabudzki, L., Miłkowski, L., Morow, K., Tomek, A, (1975): Estimates of density and number of ungulates. - Polish Ecological Studies 1: 121-135.

[68] Rich, L.N., Mitchell, M.S., Gude, J.A., Sime, C.A. (2012): Anthropogenic mortality, intraspecific competition, and prey availability influence territory sizes of wolves in Montana. - Journal of Mammalogy 93: 722-731.

[69] Ripple, W.J., Estes, J.A., Beschta, R.L., Wilmers, C.C., Ritchie, W.G., Hebblewhite, M., Berger, J., Elmhagen, B., Letnic, M., Nelson, M.P., Schmitz, O.J., Smith, D.W., Wallach, A.D., Wirsing, A.J. (2014): Status and ecological effects of the World's largest carnivores. - Science 343: 1241484.

[70] Schede, J.-U., Schumann, G., Wersin-Sielaff, A. (2010): Wölfe in Brandenburg-eine spurensuche im märkischen Sand. - Ministerium für Umwelt, Gesundheit und Verbraucherschutz des Landes Brandenburg, Potsdam (in German).

[71] Shepard D.B., Kuhns A.R., Dreslik M.J., Phillips C.A. 2008. Roads as barriers to animal movement in fragmented landscape. - Animal Conservation 11: 188-296.

[72] Stenglein, J. L., van Deelen, T.R. (2016): Demographic and component Allee effects in Southern Lake Superior gray wolves. - PLoS ONE 11(3): e0150535.

[73] Sumiński, P. (1973): Wolf (Canis lupus L.) in history and in a contemporary world. Sylwan 11: 46-55 (in Polish).

[74] Sumiński, P. (1975): The wolf in Poland. - In: Pimlott, D.H. (ed.) Wolves. Proceedings of the First Working Meeting of Wolf Specialists and of the First International Conference on Conservation of the Wolf. International Union for Conservation of Nature and Natural Resources, Morges.

[75] Thiel, R.P. (1985): The relationships between road densities and wolf habitat in Wisconsin. - American Midland Naturalist 113: 404-407.

[76] Treichel, D., Wessel, U. (1993): The distribution of the wolf in western Poland and perspectives of its further spread to the west. Unpubished Thesis. - Fachhochschule Hildesheim/Holzminden, Fachbereich Forstwirtschaft in Göttingen, Göttingen (in German).

[77] Wabakken, P., Sand, H., Liberg, O., Bjärvall, A. (2001): The recovery, distribution, and population dynamics of wolves on the Scandinavian peninsula, 1978-1998. - Canadian Journal of Zoology 79: 710-725.

[78] Wolsan, M., Bieniek, M., Buchalczyk, T. (1992): The history of distributional and numerical changes of the wolf Canis lupus L. in Poland. - In: Bobek, B., Perzanowski, K., Regelin, W.L. (eds) Global trends in wildlife management. Proceedings of the 18th Congress International Union Game Biology, Krakow 1987. Wydawnictwo Świat Press, Krakow-Warszawa.

[79] Wydeven, A.P., Schultz, R.N., Thiel, R.P. (1995): Gray wolf (Canis lupus) population monitoring in Wisconsin 1979-1991. - In: Carbyn, L.N., Fritts, S.H., Seip, D.R. (eds) Ecology and conservation of wolves in a changing world. Canadian Circumpolar Institute, University of Alberta, Edmonton.

[80] Zajączkowski, G., Jabłoński, M., Jabłoński, T., Małecka, M., Kowalska, A., Małachowska, J., Piwnicki, J. (2015): Report on the state of forests in Poland 2014. Państwowe Gospodarstwo Leśne Lasy Państwowe, Warszawa (in Polish).

[81] Zub, K., Theuerkauf, J., Jędrzejewski, W., Jędrzejewska, B., Schmidt, K., Kowalczyk, R. (2003): Wolf pack territory marking in the Białowieża Primeval Forest (Poland). Behaviour 140: 635-648. 